\title{
LOW ENERGY CONSUMING MODIFIED COMPOSITE CEMENTS AND THEIR PROPERTIES
}

\author{
Lviv Polytechnic National University \\ 12, Bandera str., 79013 Lviv, Ukraine; tmarkiv@yahoo.com
}

Received: July 15, 2010 / Revised: July 26, 2010 / Accepted: December 25, 2010

(C) Sanytsky M., Sobol Kh., Shcturmay M., Khymko O., 2011

\begin{abstract}
It has been shown that in the conditions of aggravation of ecological problems, shortage of high-quality raw materials for the production of Portland cement clinker a promising direction of cement industry development is more extensive waste utilization as well as production of low energy consuming cement clinker and modified composite cements, characterized by high content of active mineral additives. The use of modified composite cements both in mortars and concretes provides their high quality and durability and is of great social benefit in terms of resources preservation, energy saving, and environmental friendliness.
\end{abstract}

Keywords: modified composite cements, clinker, fly ash, alkali activation.

\section{Introduction}

One of the main tendencies of the world cement industry is development of low energy consuming cements, which contain greater amount of mineral additives and some chemical modifiers that accelerate binders hardening, improve their physico-mechanical properties, durability, and profitability. The most widely used material of construction industry is Portland cement, which is both resource- and energy- intensive material - production of each ton of the cement requires about 1.5 tons of raw materials and about 4000 to $7500 \mathrm{MJ}$ of energy. The cost of energy necessary to produce a ton of cement is estimated to account for $40-45 \%$ of the total production cost. Moreover, in the production process of one tone of cement 1.0 to 1.2 tons of $\mathrm{CO}_{2}$ are emitted into the atmosphere $[1,2]$.

Modern cement technology is based on the production of alite Portland cement clinkers with high $\mathrm{SF}=0.90-0.92$ value and above 60 mas $\%$ content of the main clinker mineral $\mathrm{C}_{3} \mathrm{~S}$, resulting in essential fuel consumption and determining high energy intensity of clinker formation process. Replacing part of the natural raw material by industrial waste and usage of bituminous coal instead of natural gas during clinkering will give an opportunity to considerably save material and energy resources [3, 4].

Adding fly ash and ash-slag mix to raw materials mix provide a possibility of partial replacement of natural raw materials by industrial waste. Adding ash-slag mix and fly ash to raw material mixes containing marls with increased calcium carbonate $\left(\mathrm{CaCO}_{3}\right)$ content is of particular interest, since it is important during alite Portland cement production.

Pursuing the purpose of saving natural raw materials and energy resources in the advanced countries the part of multicomponent cements constantly increases. The production of multicomponent cements enables not only to save fuel and energy (by 30-40 \%), but also to increase the volumes of concrete production.

\section{Experimental}

Chemical composition of Portland cement raw materials, specifically limestone marl of different benches and ash-slag mix (Table 1), is represented by oxides, which are able to form main phases of Portland cement clinker. Thus marl from $\mathrm{I}$ to $\mathrm{V}$ benches is characterized by the reduction of calcium oxide $\mathrm{CaO}$ content and increase of $\mathrm{SiO}_{2}, \mathrm{Al}_{2} \mathrm{O}_{3}$, and $\mathrm{Fe}_{2} \mathrm{O}_{3}$ oxides.

Phase composition analysis of the raw materials shows that limestone is characterized by calcium carbonate lines $(d / n=0.303 ; 0.250 ; 0.228 ; 0.209 ; 0.191 ; 0.187 \mathrm{~nm})$. $\mathrm{X}$-ray phase analysis of marl from $\mathrm{I}$ and $\mathrm{V}$ benches confirms the presence of less intensive calcium carbonate lines $(d / n=0.303 ; 0.228 ; 0.191 \mathrm{~nm})$, whose intensity decrease from I to $\mathrm{V}$ marl benches, and $\beta$-quartz lines $(d / n=0.424 ; 0.334 ; 0.154 \mathrm{~nm})$. However, marl from I to $\mathrm{V}$ benches demonstrate increased clay material component, which is mainly represented by montmorillonite $(d / n=0.447 ; 0.342 ; 0.260 ; 0.151 \mathrm{~nm})$ and low amount of kaolin $(d / n=0.714 ; 0.357 ; 0.147 \mathrm{~nm})$. 
Raw materials and coal ash chemical composition

\begin{tabular}{|c|c|c|c|c|c|c|c|c|}
\hline $\begin{array}{c}\text { Raw } \\
\text { components }\end{array}$ & LOI & $\mathrm{SiO}_{2}$ & $\mathrm{Al}_{2} \mathrm{O}_{3}$ & $\mathrm{Fe}_{2} \mathrm{O}_{3}$ & $\mathrm{CaO}$ & $\mathrm{MgO}$ & $\mathrm{SO}_{3}$ & $\Sigma$ \\
\hline Marl I & 34.44 & 16.30 & 3.71 & 1.69 & 42.30 & 0.50 & 0.11 & 99.05 \\
\hline Marl III & 31.57 & 20.59 & 5.31 & 1.91 & 38.52 & 0.70 & 0.22 & 98.82 \\
\hline Marl V & 29.44 & 25.93 & 5.55 & 2.20 & 33.87 & 0.99 & 0.25 & 98.23 \\
\hline Limestone & 41.86 & 2.13 & 0.32 & 0.35 & 53.55 & 0.18 & 0.06 & 98.45 \\
\hline Pyrite & 4.62 & 11.09 & 2.54 & 76.40 & 0.52 & 1.32 & 2.70 & 99.19 \\
\hline Ash-slag mix & 0.00 & 55.20 & 25.0 & 11.4 & 2.49 & 1.33 & 0.00 & 95.42 \\
\hline Coal ash & 0.00 & 50.43 & 25.22 & 12.39 & 4.10 & 2.74 & 1.76 & 96.64 \\
\hline
\end{tabular}

Slag is represented as a glassy matter with some quantity of $\beta$-quartz $(d / n=0.424 ; 0.334 \mathrm{~nm})$ and melilite $\mathrm{Ca}_{2}(\mathrm{Al}, \mathrm{Mg}, \mathrm{Si}) \cdot \mathrm{Si}_{2} \mathrm{O}_{7}(d / n=0.285 ; 0.252 ; 0.193 \mathrm{~nm})$. At the fly ash X-ray patterns only $\beta$-quartz lines are indicated $(d / n=0.424 ; 0.334 ; 0.181 \mathrm{~nm})$. Ash-slag mix contains crystallized glassy phase of substance, which could not be clearly indicated by X-ray phase analysis.

Clinkers of Ivano-Frankivsk and Mykolaiv cement plants were used for the investigations. Mineralogical compositions of these clinkers are as following, mas \%: Ivano-Frankivsk cement plant $-\mathrm{C}_{3} \mathrm{~S}-60.20 ; \mathrm{C}_{2} \mathrm{~S}-16.88$; $\mathrm{C}_{3} \mathrm{~A}-5.60 ; \mathrm{C}_{4} \mathrm{AF}-14.62$ and Mykolaiv cement plant $\mathrm{C}_{3} \mathrm{~S}-61.20 ; \mathrm{C}_{2} \mathrm{~S}-16.98 ; \mathrm{C}_{3} \mathrm{~A}-6.25 ; \mathrm{C}_{4} \mathrm{AF}-12.12$. Granulated blast furnace slag and fly ash were used as mineral additives. Fly ash of Burshtyn power station as a silico-aluminous additive contains active $\mathrm{SiO}_{2}$ and $\mathrm{Al}_{2} \mathrm{O}_{3}$ (52.41 and 24.62 mas \%, respectively) as well as some other oxides.

Physico-mechanical tests of cements and concretes were carried out according to common procedures. X-ray phase analysis was used for investigation of hydration processes of cement compositions.

\section{Results and Discussion}

Taking into account properties of the raw materials, optimization of raw mixes for energy-saving technologies of Portland cement clinker has been performed. Analyses have shown that raw mix composition which contains limestone, marl, and pyrites is characterized by increased saturation factor value and reduced silica module, which is due to the lack of aluminum silicate component and could result in the liquid phase increase at the burning zone and in cement kiln fuse. In order to obtain resource saving raw mix a corresponding amount of ash-slag mix was added instead of 5 mas \% of limestone, taking into account ash additive from bituminous coal firing instead of the part of natural gas, which made up $1.17 \%$ of clinker mass. The following raw materials mix composition and mineralogical clinker composition were calculated (Table 2).

A method of orthogonal central composition planning was used for optimization of the raw mix composition in the given saturation factor variation interval (SF) $\mathrm{X}_{1}(0.90-0.94)$ and silica module $(n) \mathrm{X}_{2}(2.0-2.4)$.

The method of mathematical planning of an experiment was used to establish an optimal raw mix composition: 44.98 mas \% of marl; 2.65 mas \% of ash-slag mix; 50.3 mas \% of limestone, and 2.07 mas \% of pyrite.

The figure shows that increase of saturation factor from 0.90 to 0.94 causes increase of the alite content and reduction of clinker minerals $\mathrm{C}_{2} \mathrm{~S}, \mathrm{C}_{3} \mathrm{~A}$, and $\mathrm{C}_{4} \mathrm{AF}$ content. At the same time increase of silica module causes increase of $\mathrm{C}_{3} \mathrm{~S}, \mathrm{C}_{2} \mathrm{~S}$, and $\mathrm{C}_{3} \mathrm{~A}$ minerals amount and reductions of $\mathrm{C}_{4} \mathrm{AF}$.

Table 2

Planning matrix and results of the complete two factor experiment

\begin{tabular}{|c|c|c|c|c|c|c|c|c|c|c|c|}
\hline \multirow{3}{*}{ No. } & \multirow{2}{*}{\multicolumn{2}{|c|}{ Planning matrix }} & \multirow{3}{*}{$\mathrm{p}$} & \multicolumn{4}{|c|}{ Raw components } & \multicolumn{4}{|c|}{ Mineralogical clinker composition } \\
\hline & & & & \multirow{2}{*}{ Marl } & \multirow{2}{*}{$\begin{array}{l}\text { Lime- } \\
\text { stone }\end{array}$} & \multirow{2}{*}{$\begin{array}{c}\text { Ash-slag } \\
\text { mix }\end{array}$} & \multirow{2}{*}{ Pyrite } & \multirow{2}{*}{$\mathrm{C}_{3} \mathrm{~S}$} & \multirow{2}{*}{$\mathrm{C}_{2} \mathrm{~S}$} & \multirow{2}{*}{$\mathrm{C}_{3} \mathrm{~A}$} & \multirow{2}{*}{$\mathrm{C}_{4} \mathrm{AF}$} \\
\hline & $\mathrm{SF}\left(\mathrm{X}_{1}\right)$ & $n\left(\mathrm{X}_{2}\right)$ & & & & & & & & & \\
\hline 1 & 0.90 & 2.0 & 0.91 & 44.84 & 49.61 & 2.61 & 2.94 & 58.27 & 18.84 & 4.10 & 17.43 \\
\hline 2 & 0.90 & 2.2 & 1.10 & 45.76 & 49.52 & 2.61 & 2.10 & 59.09 & 19.10 & 5.88 & 14.61 \\
\hline 3 & 0.90 & 2.4 & 1.34 & 46.55 & 49.46 & 2.60 & 1.39 & 59.79 & 19.33 & 7.40 & 12.19 \\
\hline 4 & 0.92 & 2.0 & 0.91 & 44.08 & 50.37 & 2.65 & 2.90 & 62.50 & 14.89 & 4.04 & 17.23 \\
\hline 5 & 0.92 & 2.2 & 1.10 & 44.98 & 50.30 & 2.65 & 2.07 & 63.37 & 15.10 & 5.79 & 14.43 \\
\hline 6 & 0.92 & 2.4 & 1.33 & 45.74 & 50.24 & 2.64 & 1.37 & 64.11 & 15.27 & 7.29 & 12.05 \\
\hline 7 & 0.94 & 2.0 & 0.91 & 43.34 & 51.12 & 2.69 & 2.86 & 66.62 & 11.03 & 3.98 & 17.03 \\
\hline 8 & 0.94 & 2.2 & 1.10 & 44.22 & 51.05 & 2.69 & 2.04 & 67.54 & 11.18 & 5.71 & 14.27 \\
\hline 9 & 0.94 & 2.4 & 1.33 & 44.96 & 51.01 & 2.68 & 1.35 & 68.32 & 11.31 & 7.19 & 11.91 \\
\hline
\end{tabular}



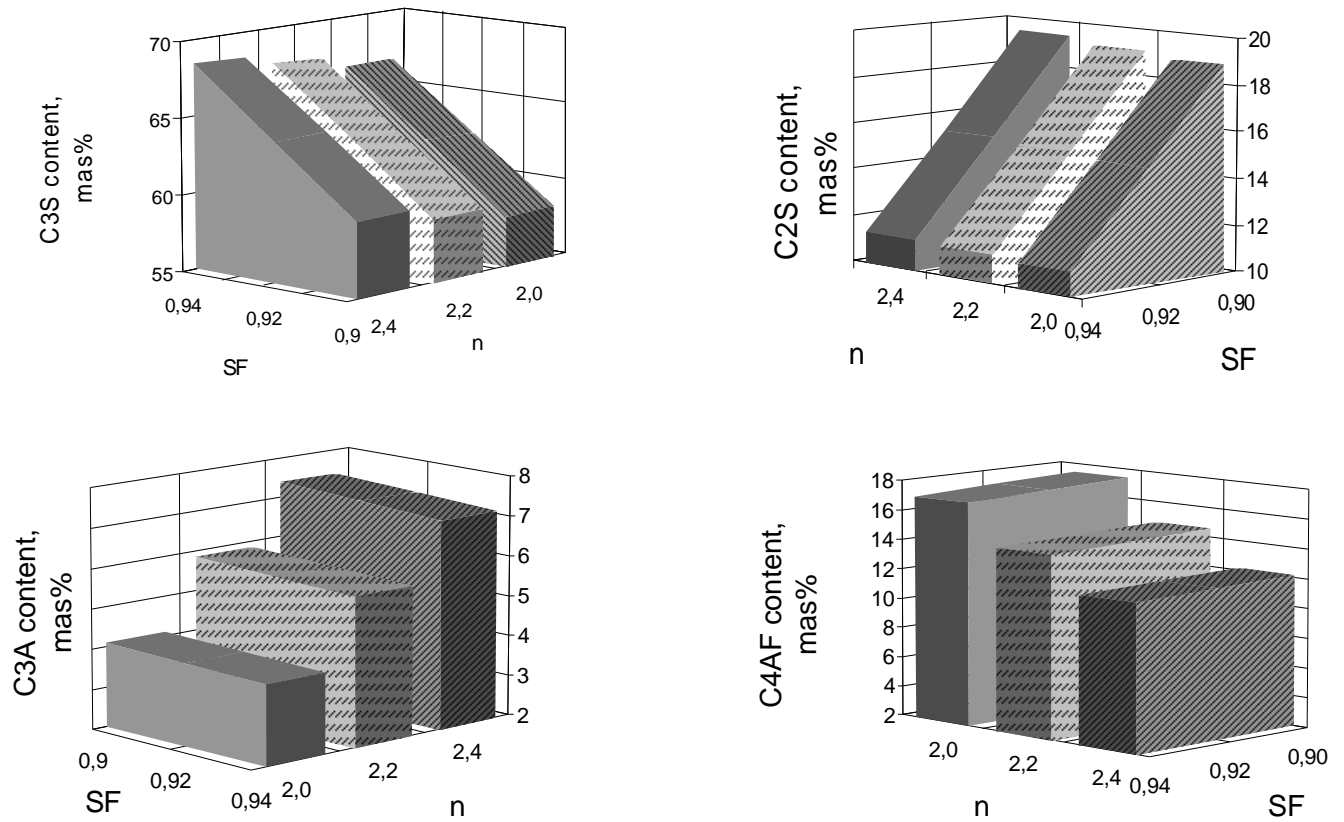

Fig. SF and $n$ influence on the content of the main clinker minerals

Thus, based on the received results raw mix compositions with partial replacement of limestone by industrial waste (ash-slag waste) and of natural gas by bituminous coal were developed. Optimal raw mix composition was established by experiment mathematical planning method: 42.73 mas \% of marl; 2.25 mas \% of ashslag mix; 52.95 mas \% of limestone, and 2.07 mas \% of pyrite. Usage of 2.25 mas \% of ash-slag mix allows to optimize main characteristics of Portland cement clinker and reduce $\mathrm{CO}_{2}$ emission to atmosphere due to decrease of calcium carbonate content in the raw mix composition.

On the basis of the optimized raw material mixes clinker has been burned, which was used for development of low energy consuming modified composite cement. According to the state standard of Ukraine and European standards EN 197 wide possibilities are created for the production of composite (multicomponent) cements such as CEM V with up to 80 mas \% of active mineral additives, and 50 mas $\%$ of fly ash in particular. It has been established that incorporation of cement replacement materials, such as granulated blast furnace slag and fly ash in combination with complex chemical admixtures make them effective additives to Portland cement. The particles of fly ash move apart grains of cement, freeing space for settling of the reaction products and thereby accelerating the speed of clinker minerals hydration ("effect of fine powders"). Growing amount of $\mathrm{Ca}(\mathrm{OH})_{2}$ causes activation of glassy phase of fly ash, accelerating chemical reactions between amorphous $\mathrm{SiO}_{2}$ and $\mathrm{Al}(\mathrm{OH})_{3}$ of fly ash and the product of the alite phase hydrolysis with the formation of hydroaluminates and hydrosilicates of calcium.
Two following processes take place during composite cement hydration: clinker minerals reaction with water and interaction of active oxides of additives with calcium hydroxide in the non-clinker part. Taking into account low content of $\mathrm{Al}_{2} \mathrm{O}_{3}$ in slag minerals, optimized ratio between blast furnace granulated slag and high aluminate fly ash to a greater degree promote formation of ettringite crystals, which destroy jellous masses of silicic acid providing access of water to internal grain layers. Hardening of composite cement could be speed up by using high alite clinkers $\left(\mathrm{SF}=0.92, \mathrm{C}_{3} \mathrm{~S}: \mathrm{C}_{2} \mathrm{~S}>3\right.$ ) as well as by finer grinding and replacement of a part of two-hydrous gypsumby 1-2 mas \% sodium sulfate additives. Sulfatealkaline activation speeds-up alite phase hydrolysis with calcium hydroxide release and interaction with active mineral additives in a non-clinker part of cement.

The main reason of strength increase of cement stone on the basis of CEM V/A is higher amount of $\mathrm{AF}_{\mathrm{t}}$-phase at early-age structure formation and formation of extra amount of low basic hydrosilicates of type CSH(B). The presence of some quantities of fine crystal hydrogelenite and blended alkali-earth hydroaluminosilicates in hydration products of modified composite cements is important. Hydrogelenite, known as stratlengite $\left[\mathrm{Ca}_{2} \mathrm{Al}(\mathrm{OH})_{6}\right]$ $\left[\mathrm{AlSiO}_{3}(\mathrm{OH})_{2} \cdot 4 \mathrm{H}_{2} \mathrm{O}\right]$, refers to $\mathrm{AF}_{\mathrm{m}}$-phases and is a crystalchemical analog of $\mathrm{C}_{2} \mathrm{AH}_{8}$, in which anions $\left[\mathrm{AlSiO}_{3}(\mathrm{OH})_{2}\right]^{-}$ are placed between portlandite-like layers $\left[\mathrm{Ca}_{2} \mathrm{Al}(\mathrm{OH})_{6}\right]^{+}$. Formation of $\mathrm{C}_{2} \mathrm{ASH}_{8}$ promotes stabilization of hexagon hydrate phases of the stone on the basis of composite cements. 
The obtained results allow to extend the interpretation of the concept of active mineral additives depending on the $\mathrm{Al}_{2} \mathrm{O}_{3}$ content and mechanism of interaction of mineral additives in alkali activated hardening cement systems. High aluminate mineral additives (fly ash and zeolit) in aluminosilicate carcass contain $\mathrm{Al}^{3+}$ ions of metastable tetraedric coordination, which change anion formation function for the cation formation one in the process of interaction during formation of $\mathrm{AF}_{\mathrm{m}}$ structure and $\mathrm{AF}_{\mathrm{t}}$-phases. Taking into account active role of aluminate component the following groups of mineral additives can be marked out: i) hydraulic action group $\mathrm{CaO}-\mathrm{SiO}_{2}-\mathrm{Al}_{2} \mathrm{O}_{3}$ systems (granulated blast furnace slag, characterized by lower content of $\mathrm{Al}_{2} \mathrm{O}_{3}$ (5-7 mas \%); ii) pozzolanic action group - high siliceous additives of $\mathrm{SiO}_{2}$ system (opoka, diatomite) and siliceous high aluminate additives (20-30 mas \% of $\mathrm{Al}_{2} \mathrm{O}_{3}$ ) of $\mathrm{Al}_{2} \mathrm{O}_{3}-\mathrm{SiO}_{2}$ system (fly ash, burnt rock); alkali containing siliceous medium aluminate (14-16 mas \% of $\left.\mathrm{Al}_{2} \mathrm{O}_{3}\right)$ additives of $\mathrm{Na}_{2} \mathrm{O}$ $\mathrm{Al}_{2} \mathrm{O}_{3}-\mathrm{SiO}_{2}$ system (zeolit, perlite); iii) carbonate additives - active components with regard to aluminate and alumoferrite phases and fillers.

With the purpose of unification of cements qualitative parameters, the modified composite cements were tested according to GOST 310.1-4 and EN 196. It was shown, that the developed composite cement may be referred to class CEM V/A 32.5 and is characterized by high plasticity. At the same water : cement ratio $(\mathrm{W} / \mathrm{C}=0.4)$ fly ash containing composite cements are characterized by increased plasticity and compressive strength on $69 \%$ in comparison with blast furnace cement. Modified cement CEM V/A is characterized by smaller hydration heat, shrinkage deformations and higher corrosion resistance.

Modified multicomponent cements with considerable content of mineral additives are characterized by higher efficiency and provide:

- reduction of cement production facilities due to the increase of the content of cheap waste constituents;

- utilization of industrial wastes of power engineering and metallurgy, which brings economic and social benefit;

- decrease of $\mathrm{CO}_{2}$ emission to the atmosphere from 0.8-1.2 to 0.2-0.4 tons of $\mathrm{CO}_{2}$ per ton of cement as a result of replacement of clinker by mineral additives.

Depending on a class and type of cement, modified composite cements with fly ash additive can be used for the production of ordinary concretes as well as concretes for special application: SCC, massive and hydrotechnical constructions. Such cements are recommended also for production of concretes resistant to alkaline and sulfate corrosion. CEM V/B cement can be used for the production of mortars as well as a binder in road building for soil stabilization. The concrete mixes based on the modified composite cement CEM V/A are characterized by reduced water consumption while concretes have improved frost resistance and waterproofness.

\section{Conclusions}

The use of by-products and industrial waste both as main raw materials as well as corrective additives in raw mixes is one of the ways of reduction of resource intensity of the cement production, complex use of raw materials, and in some cases reduction of fuel consumption in clinker production. Usage of ash-slag mix allows to optimize Portland cement clinker main characteristics and reduce $\mathrm{CO}_{2}$ emission to atmosphere due to calcium carbonate content reduction in the raw mix composition.

Sulfate-alkaline activation of mineral additions of composite cements by polyfunctional modifiers and formation of additional amount of ettringite and hydrosilicates $\mathrm{CSH}(\mathrm{B})$ as well as the presence of fine crystal hydrogelenite $\left[\mathrm{Ca}_{2} \mathrm{Al}(\mathrm{OH})_{6}\right]\left[\mathrm{AlSiO}_{3}(\mathrm{OH})_{2} \cdot 4 \mathrm{H}_{2} \mathrm{O}\right]$ and mixed alkali-earth hydroaluminosilicates $\left(\mathrm{Na}_{2} \mathrm{O} \cdot \mathrm{Al}_{2} \mathrm{O}_{3} \cdot 4 \mathrm{SiO}_{2} \cdot 2 \mathrm{H}_{2} \mathrm{O}\right.$ and others $)$ as hydration products of composite cements provides synthesis of cement stone strength. An extended approach to interpretation of active mineral additives (granulated blast furnace slag, zeolit, fly ash), taking into account the content of $\mathrm{Al}_{2} \mathrm{O}_{3}$ and sulphatealkali activation, was proposed. Conditions of the most complete realization of the potential binding properties of composite cements due to synergetic action of complex organic-mineral additives were ascertained.

\section{References}

[1] Swamy R.: Proc. Mario Collepardi Symposium on Advances in Concrete Science and Technology. Italy, Rome 1997, 127.

[2] Giergiczny Z., Malolepszy J., Szwabowski J. and Sliwinski S.: Cement z Dodatkami Mineralnymi w Technologii Betonów Nowej Generacji. Wydawnictwo Instytut Slaski SP. z O.O, Opole 2002.

[3] Krivenko P.: IBAUSIL. 14 Internationale Baustofftagung. Band 1. Germany, Weimar 2000, 0503.

[4] Sanytsky M., Markiv T., Kropyvnytska T. and Kruts T.: $3^{\text {rd }}$ International Symposium "Non-traditional Cement and Concrete". Czech Republic, Brno 2008, 697.

\section{НИЗЬКОЕНЕРГОСМНІ МОДИФІКОВАНІ КОМПОЗИЦЙНІ ЦЕМЕНТИ ТА ЇХ ВЛАСТИВОСТІ}

Анотація. Показано, щуо в умовах загострення екологічних проблем, зменшення запасів високоякісних сировинних матеріалів для виробництва портландиементного клінкеру, перспективним напрямком розвитку цементної промисловості $\epsilon$ иириа утилізачія відходів, а також виробництво низькоенергоємних клінкерів та модифікованих композичійних иементів, які характеризуються підвищеним вмістом активних мінеральних добавок. Використання модифікованих композиційних цементів як в розчинах, так $і$ бетонах забезпечує їх високу якість та довговічність з величезною сочіальною користю в сенсі ресурсів, енергї і навколишнього середовища.

Ключові слова: модифіковані композиційні иементи, клінкер, зола винесення, лужна активація. 